\title{
Fruit and Vegetables as a Potential Source of Alternative Electrical Energy
}

\author{
Syifa Fauzia ${ }^{*}$, Muhammad Abdul Haq Ashiddiqi ${ }^{1}$, Alfiatun Wa'is Khusnul Khotimah ${ }^{2}$ \\ ${ }^{1}$ Physics Department, ${ }^{2}$ Biology Education Department, Faculty of Science and Technology, UIN Sunan Kalijaga \\ Jl. Marsda Adisucipto No. 1 Yogyakarta 55281, Indonesia. Tel. + 62-274-540971, Fax. + 62-274-519739 \\ "Email: syifafz1@gmail.com
}

\begin{abstract}
From the total municipal organic waste, around $60 \%$ are vegetables and $40 \%$ are leaves, fruit peels and leftovers. In fruits contain substances such as ascorbic acid, citric acid and NADH (Nicotinamide Adenosine Dinucleotide Hydrogen, that produces cell energy), which under certain conditions these chemicals act as electrolytes. From the electrical properties that contain a lot of electrolytes from fruit and vegetable waste can be used as a renewable alternative energy source in the form of bio-batteries as a substitute for conventional batteries. The development of waste fruits and vegetables as bio-batteries will contribute greatly to the world of science in particular, and society in general. Data collection from previous studies was carried out and then analyzed based on existing parameters. There are various parameters related to the electrical properties of fruits and vegetables. Different types of fruits and vegetables produce different currents and voltages. Fruits and vegetables have different $\mathrm{pH}$ (acidity), where $\mathrm{pH}$ is inversely proportional to current and voltage. In addition, the type of electrode used also affects the electrical properties. The distance between electrodes is inversely proportional to current and voltage in fruit and vegetable waste. Installing bio-batteries in series and parallel can increase current and voltage. Bio-batteries with a higher voltage will produce longer LED flash times.
\end{abstract}

Keywords: Bio-batteries, Organic waste, Renewable alternative energy

Abbreviations: NADH (Nicotinamide Adenosine Dinucleotide Hydrogen)

\section{INTRODUCTION}

Energy sources are very abundant in nature, from nonrenewables such as petroleum, to renewable energy sources which are currently hotly discussed and developed such as sunlight, geothermal energy, and wind. Of all energy sources, renewable energy is expected to be the hope of future energy sources because of its superiority that is available continuously, environmentally friendly, and abundant.

Battery is a device that can generate electrical energy by involving the transfer of electrons through a conductive medium of two electrodes (anode and cathode) so as to produce an electric current and a difference in potential difference. The main component of the battery consists of electrodes and electrolytes. (Kartawidjaja et al., 2008) Electrolytes or ionic conductors serve as providers of means to transfer ions.

The working principle of the battery uses the principle of electrochemistry by utilizing a process of reduction-oxidation where the negative electrode (anode) will experience an oxidation reaction so that the electrons on the surface of the anode will be released and carried by the electrolyte ion to the positive electrode (cathode). The transfer of electrons by electrolyte ions will then produce a voltage difference and an electric current if connected or coupled with electronic components such as diodes, resistors or capacitors (Kartawidjaja et al., 2008). Electrochemistry is a redox reaction which in this reaction the energy released by a spontaneous reaction is converted into electricity or electrical energy is used so that non-spontaneous reactions can occur (chang, 2004).

According to Jauharah (2013) fruits and vegetables can be used as alternative renewable energy sources in the form of bio-batteries as a substitute for conventional batteries because they have electrical properties that contain a lot of electrolytes. When fruits and vegetables begin to decompose, a chemical process known as fermentation occurs. During this process, fruits and vegetables produce more acid which increases electrolyte strength in fruits and vegetables. Thus, juices from ripe or rotten fruits and vegetables become more reactive with electrodes and produce higher stresses than fresh fruit or vegetable juices. (Amin et al., 2005)

Sucipto (2007) trial in Imamah (2013) also proved that banana and orange peels can be used as a direct source of electric current. The results of the research showed that the average voltage generated by a dry battery with a banana skin electrolyte was 1.24 volts. Resistance in wall hours averaged 5 days 6 hours (135 hours).

In this study will be studied the potential use of fruits and vegetables for energy sources in the form of bio-battery which aims to determine parameters related to fruits and vegetables as an alternative energy source. This study aims to determine the electrical parameters, acidity and the best composition produced by biobatteries of various types of fruits and vegetables in their use as bio-batteries. 


\section{MATERIALS AND METHODS}

This writing method is by looking for literature about fruits and vegetables as a source of electrical energy. Data collection from previous studies was carried out and then analyzed based on existing parameters. Data collection and analysis is carried out on 29 November to 11 December 2017.

\section{RESULTS AND DISCUSSION}

\section{Electrical Properties by Various Kinds of Fruits and Vegetables}

Fruits and vegetables have various electrical properties. Research conducted by Muhlisin et al (2015) compared banana peels and durian peel as a battery stone paste. The resulting voltage shows the electrical properties of each. The maximum stress value obtained from banana peel paste is greater than durian peel, namely 1.12 volt banana peel and 0.99 volt durian peel. And ambon bananas are the best bananas used in this experiment as a substitute for battery stone paste.

Table 1. Results of voltage measurement banana peel ambon (Muhlisin, 2015).

\begin{tabular}{lllll}
\hline No & Weight (gr) & $\begin{array}{l}\text { Electrolyte } \\
\text { Mass (gr) }\end{array}$ & $\begin{array}{l}\text { Voltage } \\
(\mathbf{V})\end{array}$ & $\begin{array}{l}\text { Current } \\
(\mathbf{m A})\end{array}$ \\
\hline 1 & 34 & 19 & 0,62 & 0,12 \\
2 & 34 & 19 & 0,68 & 1 \\
3 & 34 & 20 & 0,85 & 2,7 \\
4 & 34 & 20 & 0,89 & 2,85 \\
5 & 34 & 21 & 0,95 & 4 \\
6 & 34 & 22 & 1 & 5 \\
7 & 34 & 22 & 1 & 5,5 \\
8 & 34 & 22 & 1,09 & 7,8 \\
9 & 34 & 22 & 1,09 & 9,5 \\
10 & 34 & 25 & 1,2 & 10 \\
\hline
\end{tabular}

Table 2. Results of voltage measurement janten banana peel (Muhlisin, 2015).

\begin{tabular}{lllll}
\hline No & Weight (gr) & $\begin{array}{l}\text { Electrolyte } \\
\text { Mass (gr) }\end{array}$ & $\begin{array}{l}\text { Voltage } \\
(\mathbf{V})\end{array}$ & $\begin{array}{l}\text { Current } \\
(\mathbf{m A})\end{array}$ \\
\hline 1 & 34 & 17 & 0,45 & 0,15 \\
2 & 34 & 18 & 0,51 & 0,17 \\
3 & 34 & 19 & 0,6 & 0,67 \\
4 & 34 & 20 & 0,62 & 0,82 \\
5 & 34 & 21 & 0,75 & 0,87 \\
6 & 34 & 22 & 0,77 & 2,1 \\
7 & 34 & 22 & 0,9 & 1,9 \\
8 & 34 & 22 & 1,96 & 3 \\
9 & 34 & 23 & 1 & 4 \\
10 & 34 & 25 & 1,07 & 9 \\
\hline
\end{tabular}

Table 3. Results of voltage measurement banana peel mali (Muhlisin 2015).

\begin{tabular}{lllll}
\hline No & Weight (gr) & $\begin{array}{l}\text { Electrolyte } \\
\text { Mass }(\mathbf{g r})\end{array}$ & $\begin{array}{l}\text { Voltage } \\
(\mathbf{V})\end{array}$ & $\begin{array}{l}\text { Current } \\
(\mathbf{m A})\end{array}$ \\
\hline 1 & 34 & 18 & 0,52 & 0,5 \\
2 & 34 & 19 & 0,55 & 0,55 \\
3 & 34 & 120 & 0,62 & 0,65 \\
4 & 34 & 20 & 0,62 & 0,98 \\
5 & 34 & 22 & 0,69 & 1,02 \\
6 & 34 & 23 & 0,72 & 1,5 \\
7 & 34 & 24 & 0,74 & 1,8 \\
8 & 34 & 25 & 0,8 & 2,9 \\
9 & 34 & 25 & 0,98 & 4,3 \\
10 & 34 & 25 & 1,05 & 6,5 \\
\hline
\end{tabular}

Table 4. Results of voltage measurement durian peel (Muhlisin, 2015).

\begin{tabular}{lllll}
\hline No & Weight (gr) & $\begin{array}{l}\text { Electrolyte } \\
\text { Mass (gr) }\end{array}$ & $\begin{array}{l}\text { Voltage } \\
(\mathbf{V})\end{array}$ & $\begin{array}{l}\text { Current } \\
(\mathbf{m A})\end{array}$ \\
\hline 1 & 34 & 18 & 0,45 & 0,23 \\
2 & 34 & 21 & 0,55 & 0,24 \\
3 & 34 & 22 & 0,56 & 0,37 \\
4 & 34 & 23 & 0,63 & 0,4 \\
5 & 34 & 23 & 0,8 & 0,72 \\
6 & 34 & 23 & 0,82 & 1,5 \\
7 & 34 & 24 & 0,88 & 1,7 \\
8 & 34 & 24 & 0,94 & 2,84 \\
9 & 34 & 25 & 0,95 & 7 \\
10 & 34 & 25 & 0,99 & 10 \\
\hline
\end{tabular}

The difference in electrical properties is because each substance is contained therein. Various kinds of fruits and vegetables have varying levels of acidity. This also affects the voltage generated, as the research conducted by Jauharah (2013). The relationship between $\mathrm{pH}$ and voltage generated is inversely proportional.

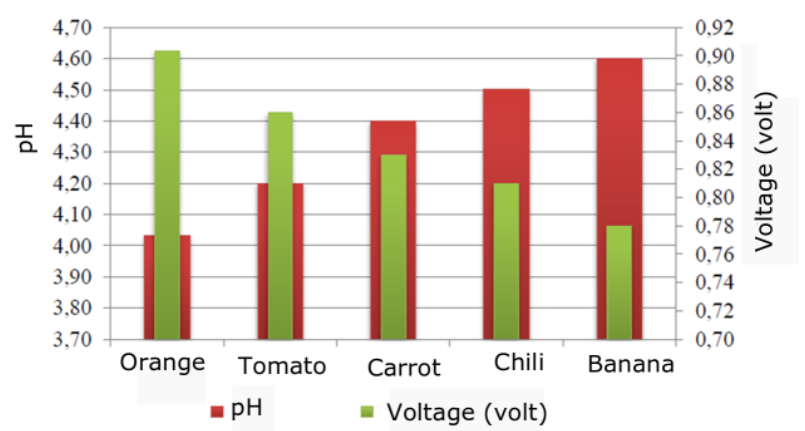

Figure 1. Relationship between $\mathrm{pH}$ value and voltage on a variety of biobatteries of fruit and vegetable waste (Jauharah, 2013). 
Another study conducted by Kholida and Pujayanto (2015) states the relationship of electric current with the acidity of citrus fruits and mangoes. $\mathrm{PH}$ is inversely proportional to the strength of the electric current.

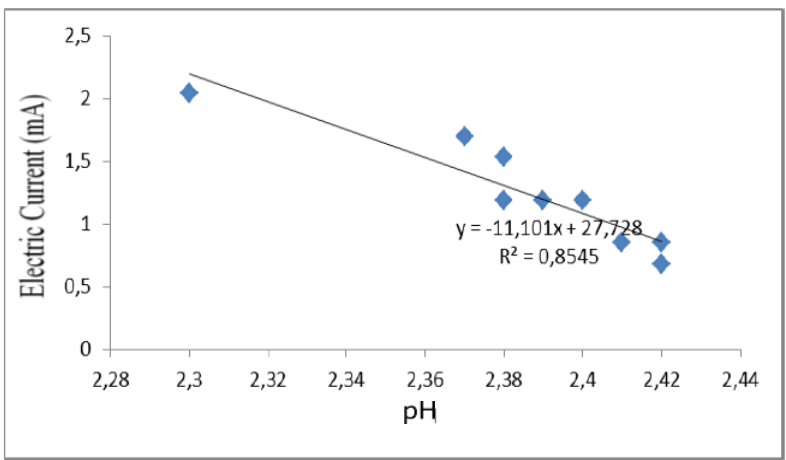

Figure 2. Relationship between $\mathrm{pH}$ and strength of electric current in fruit lime (Kholida, 2015).

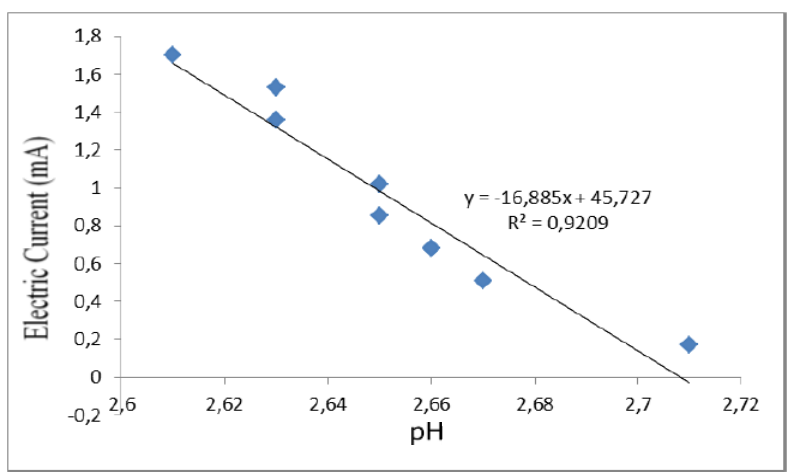

Figure 3. Relationship between $\mathrm{pH}$ and strength of electric current in fruit Pontianak oranges (Kholida, 2015).

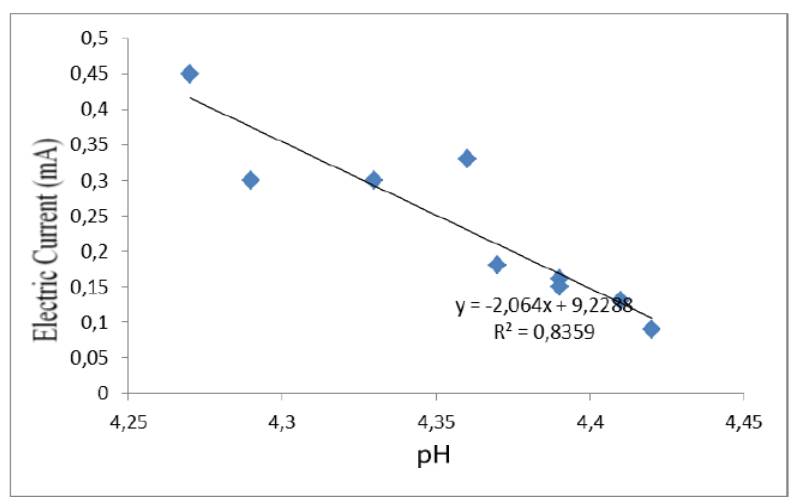

Figure 4. Relationship between $\mathrm{pH}$ and strength of electric current in fruit tangerines (Kholida, 2015).

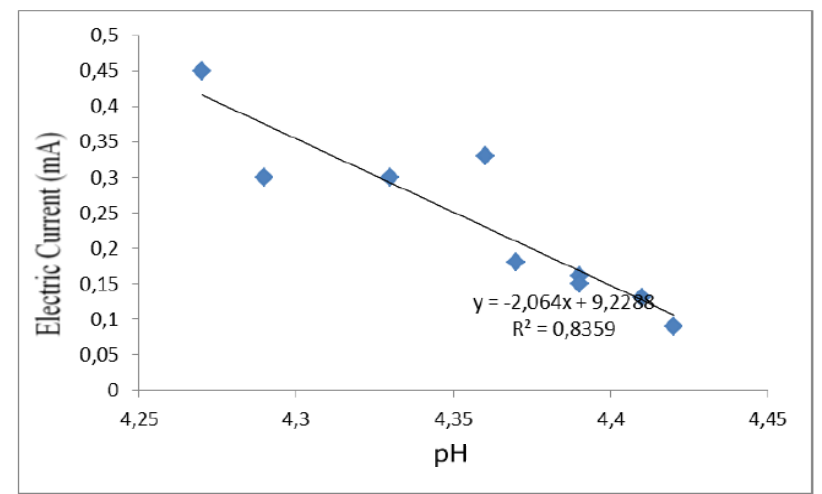

Figure 5. Relationship between $\mathrm{pH}$ and strength of electric current in fruit mango arumanis (Kholida, 2015).

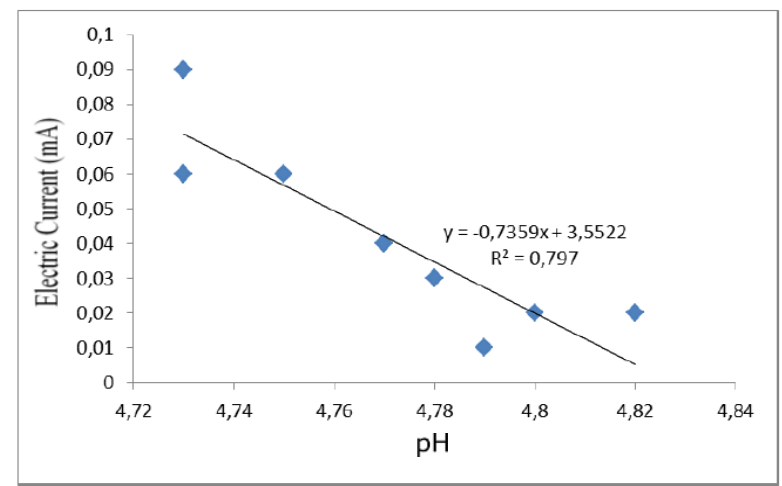

Figure 6. Relationship between $\mathrm{pH}$ and strength of electric current in fruit mango sengir (Kholida, 2015).

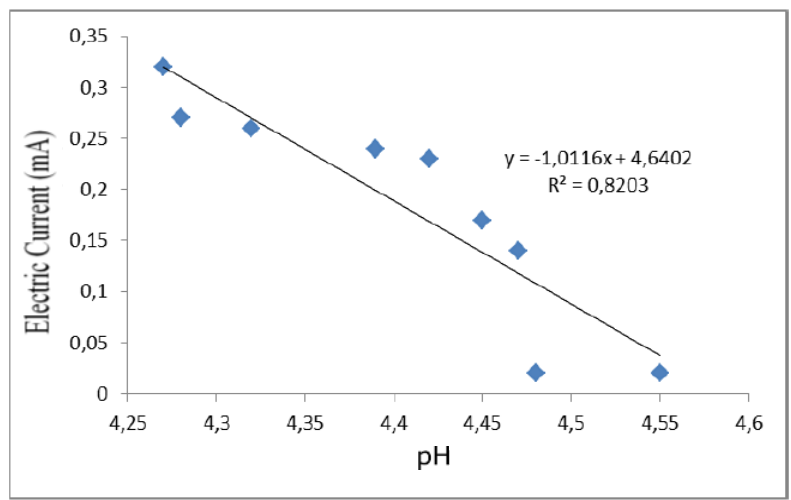

Figure 7. Relationship between $\mathrm{pH}$ and strength of electric current in fruit mango manalagi (Kholida, 2015).

\section{Effect of Electrodes on Electricity of Fruits and Vegetables}

Research conducted by Imamah (2013) studied the electrical effects caused by variations in electrode material contained in citrus fruit waste. Obtained variation of distance and pair of electrodes influence the value of the voltage and current of the battery produced. The distance between electrodes varied from $2,4,6,8$ and $10 \mathrm{~cm}$. 
Elec- Graphs of electrical current with variations in distance trode

$\mathrm{Cu}-\mathrm{Fe}$

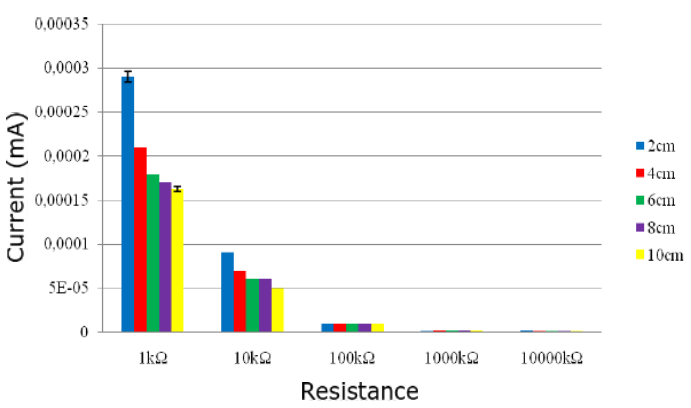

$\mathrm{Al}$

Brass

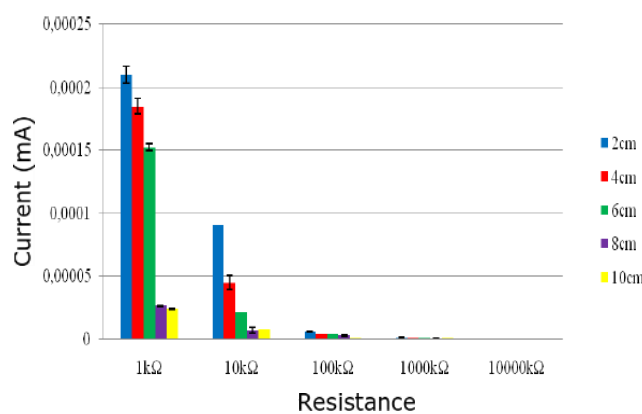

$\mathrm{Cu}-$

$\mathrm{Pb}$

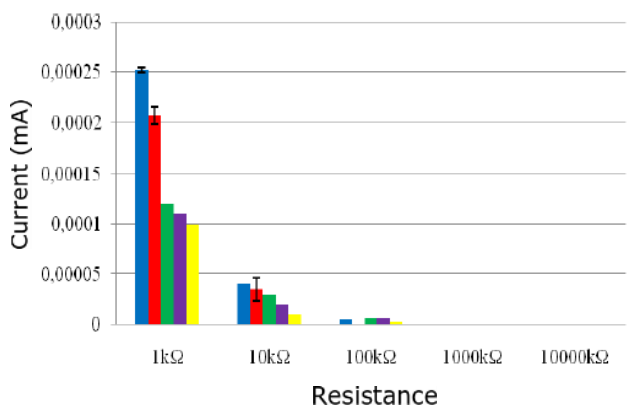

Brass

$-\mathrm{Cu}$

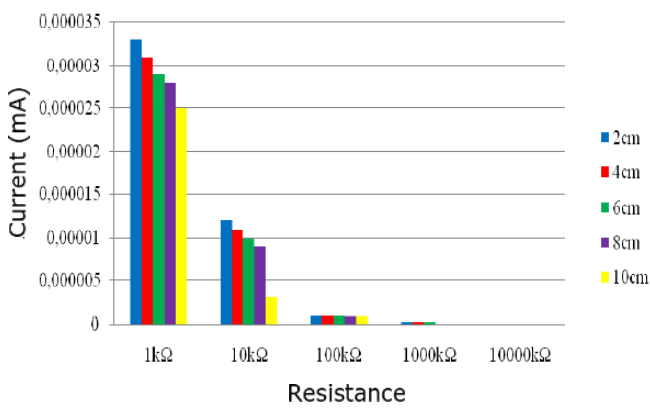

$\mathrm{Cu}-\mathrm{Al}$

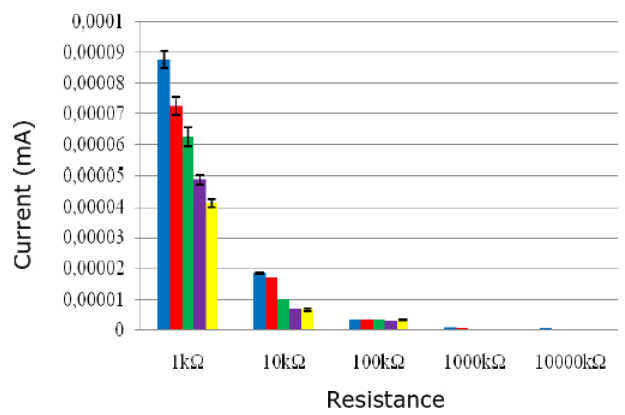

Graph of voltage values with variations in distance
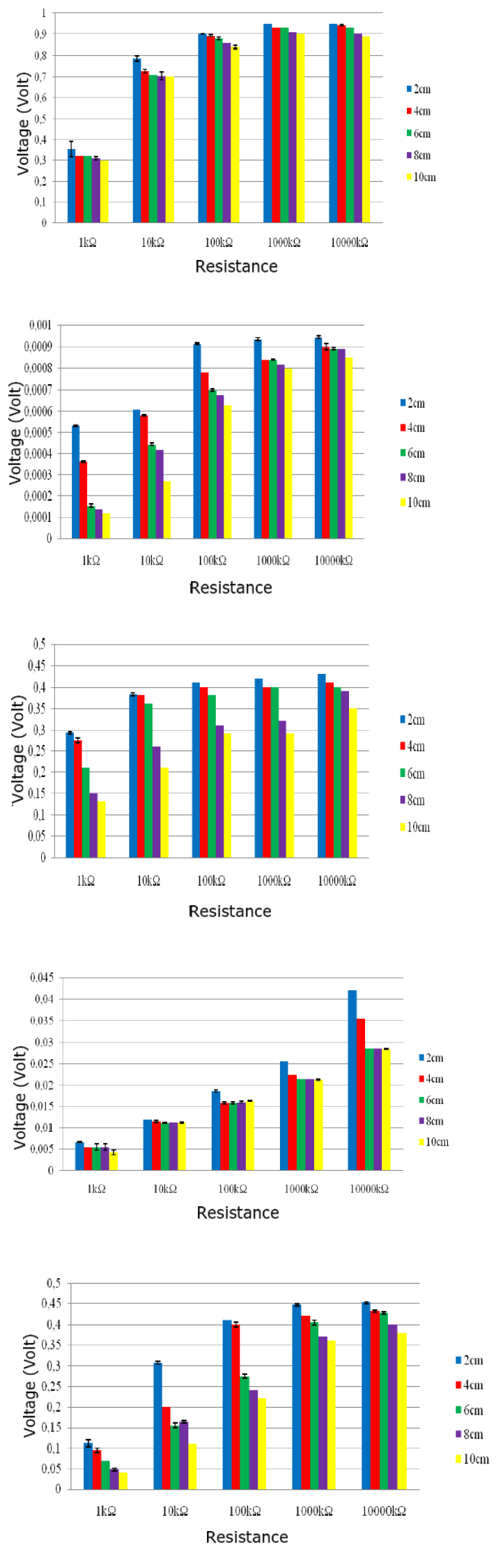

Figure 8. Electric current and voltage graph with variations distance electrodes (Imamah, 2013). 
Based on research obtained the distance between electrodes is inversely proportional to current and voltage. The smaller the electrode distance, the greater the voltage and current values generated at each pair of electrodes used. This is consistent with research conducted by Jauharah (2013) where the distance between electrodes is inversely proportional to the current and voltage strength for each variation of biobattery.
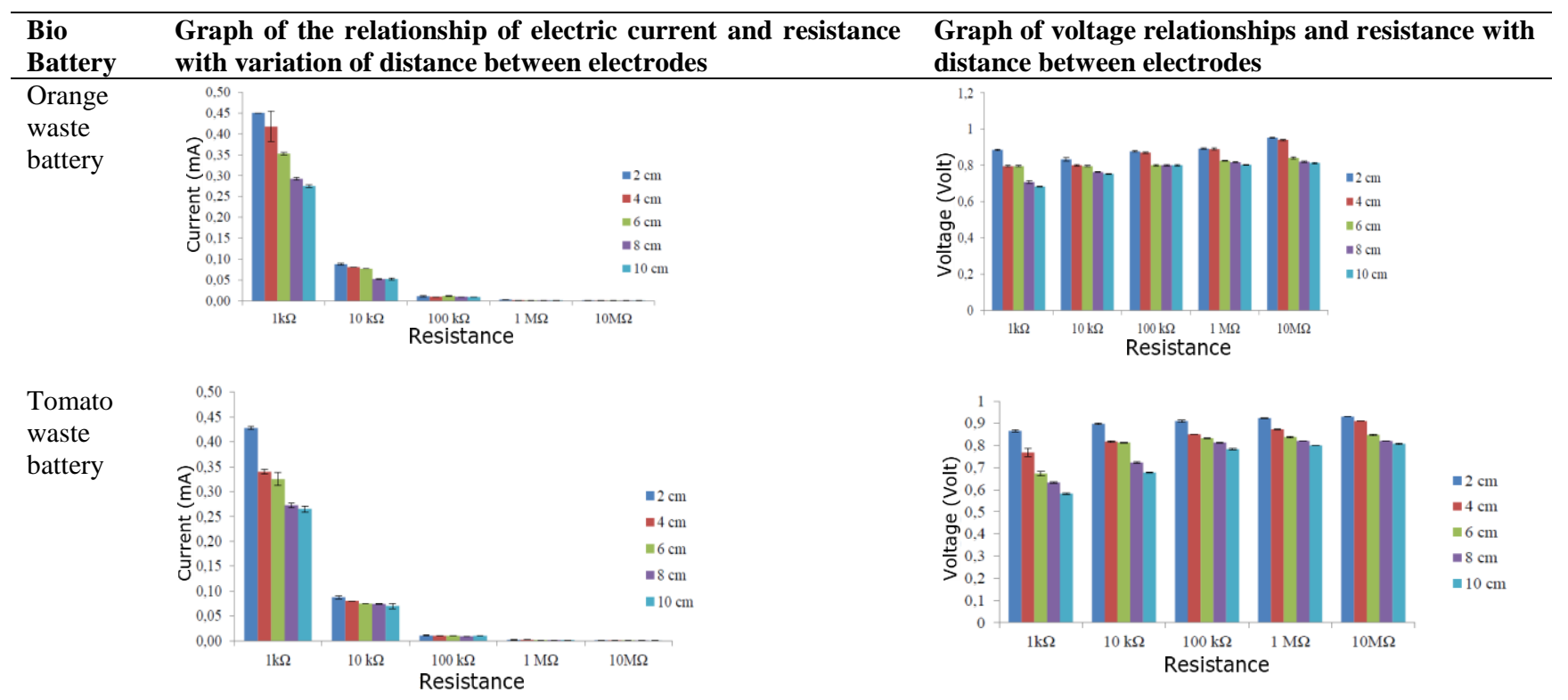

Chili
waste
battery
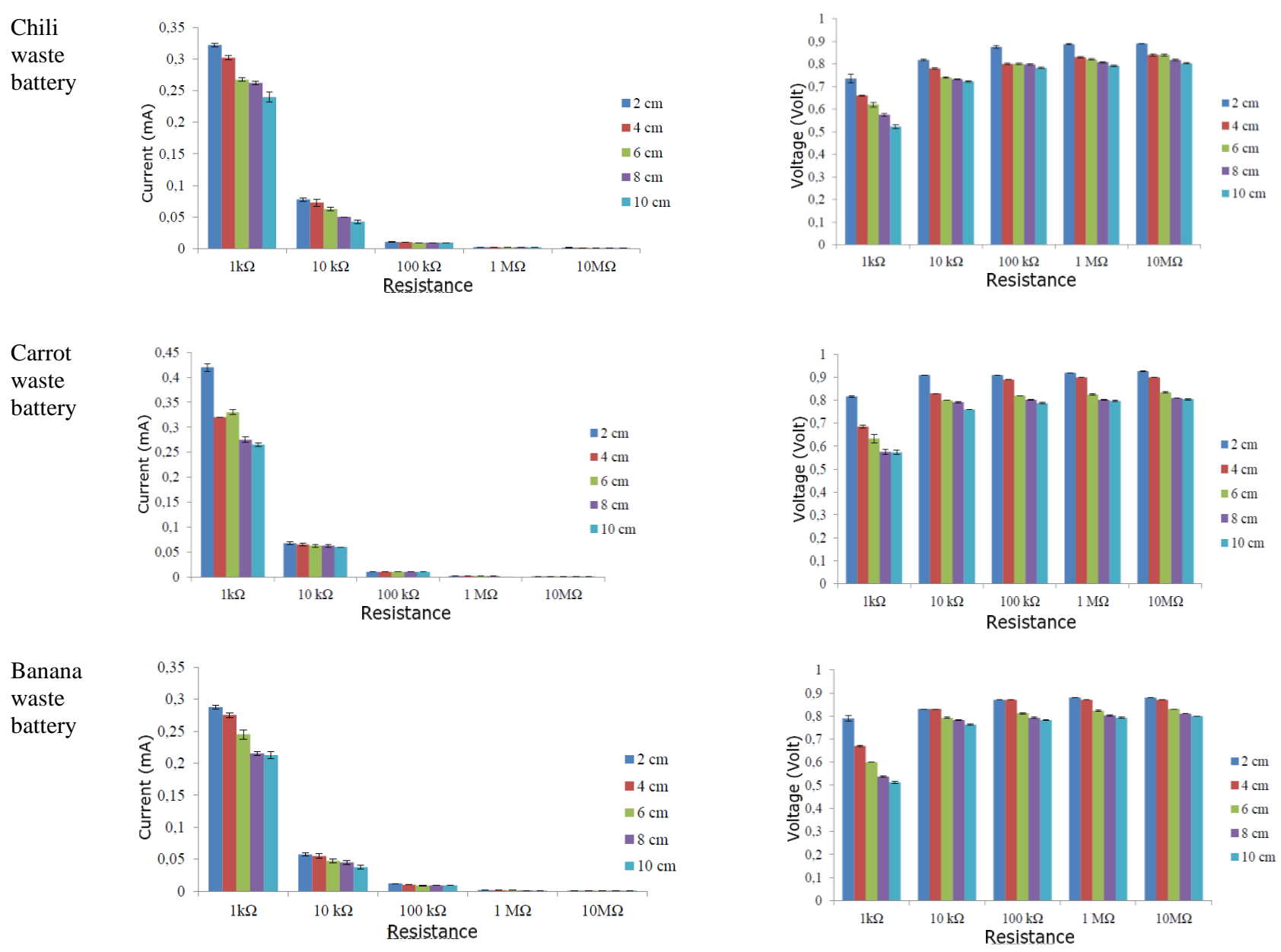

Figure 9. Graph of the relationship between electric current and voltage with distance variations between electrodes for various bio-batteries (Jauharah, 2013). 


\section{Electrical Properties of Fruit and Vegetable Waste Batteries in Parallel-Series Series}

Based on experiments carried out by Imamah (2013), the battery that is installed in parallel series, has a voltage value and the current strength is greater than that of a single battery on the same electrode pair. Resistance also affect the amount of current produced. the greater the resistance, the smaller the current value, the greater the voltage value. In this experiment, the pair of $\mathrm{Cu}-\mathrm{Fe}$ electrodes had the largest current and voltage values compared to the other electrode pairs.

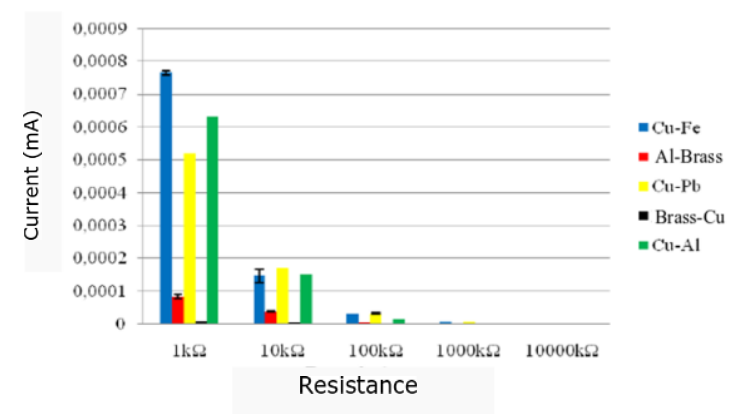

Figure 10. Graph of flow charts on bio-battery measurements in series and in parallel (Imamah, 2013).

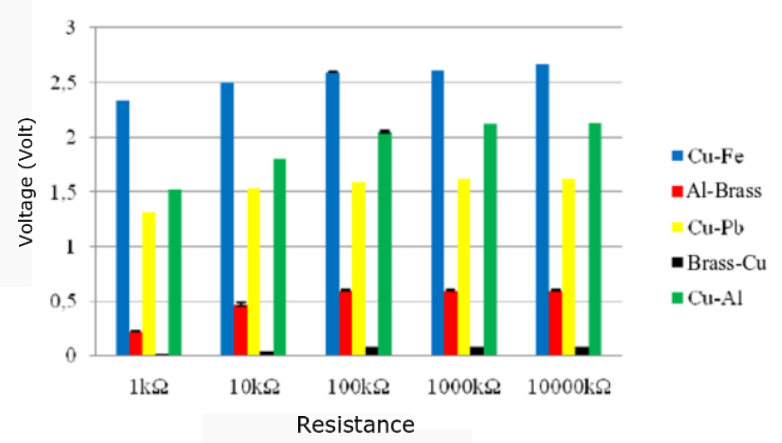

Figure 11. Series and parallel voltage charts (Imamah, 2013).

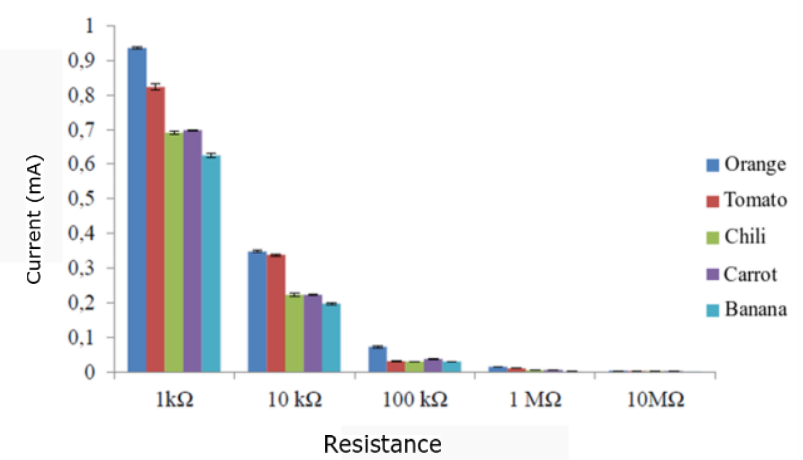

Figure 12. Graphs relationship between electric current and resistance (Jauharah, 2013).

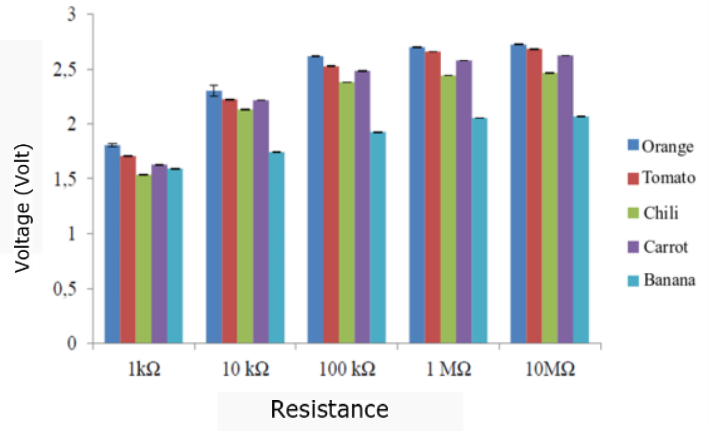

Figure 13. Graphs relationship between voltage and obstacles; in biobattery series-parallel variety of fruit and vegetable waste (Jauharah, 2013).

Similarly, the parallel-series Bio-battery experiment conducted by Jauharah (2013) resulted in nearly three times the value of a single electric current and a single bio-battery voltage. The highest current and voltage strengths are owned by bio-batteries of citrus fruit waste compared to tomatoes, carrots, peppers and bananas with a voltage of 2.72 volts.

\section{Bio-Battery Voltage Measurements and the Length of Time the LED Lights on the Parallel-Series Bio- Batteries}

The measurement of the voltage and duration of the LED lights is found in the experiment conducted by Jauharah (2013). It appears that bio-batteries with a higher voltage produce longer LED flash times. Biobatteries that are capable of turning on the longest LED lights are produced by Orange fruit waste bio-batteries with a 75-hour LED flame.

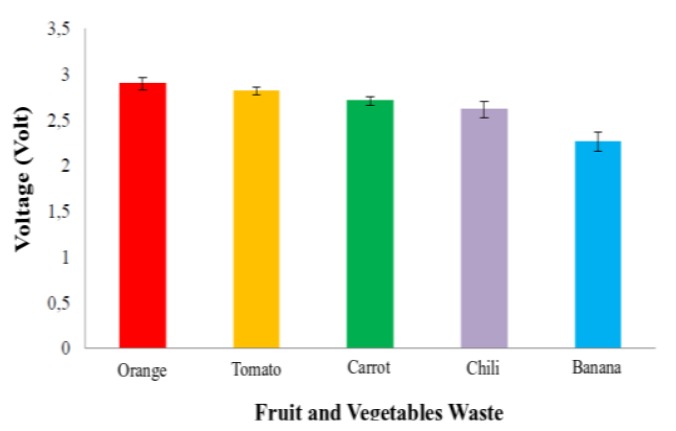

Figure 14. Average initial voltage graph (Jauharah, 2013).

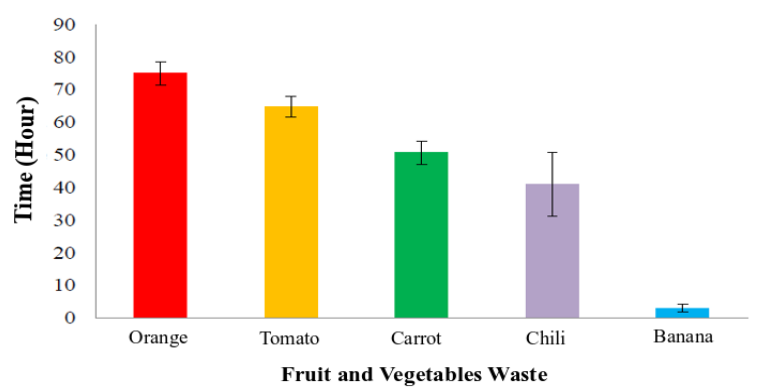

Figure 15. Graph of the LED flasht; on various bio-batteries of fruit and vegetable waste. (Jauharah, 2013). 
Similarly, in the experiments conducted by Imamah (2013), where the variation of electrodes with a higher voltage results in a longer LED flame time. Bio-battery pairing of $\mathrm{Cu}-\mathrm{Fe}$ electrodes arranged in parallel series produces the highest voltage and the longest LED flame is 1.58 volts and turns on for 18.14 hours. Whereas for other electrode pairs such as Al-brass, Brass- $\mathrm{Cu}$ and $\mathrm{Cu}-\mathrm{Al}$ cannot turn on the LED. This is because the resulting voltage is very low, which is equal to 0.43 volt, 0.33 volt and 0.67 volts.

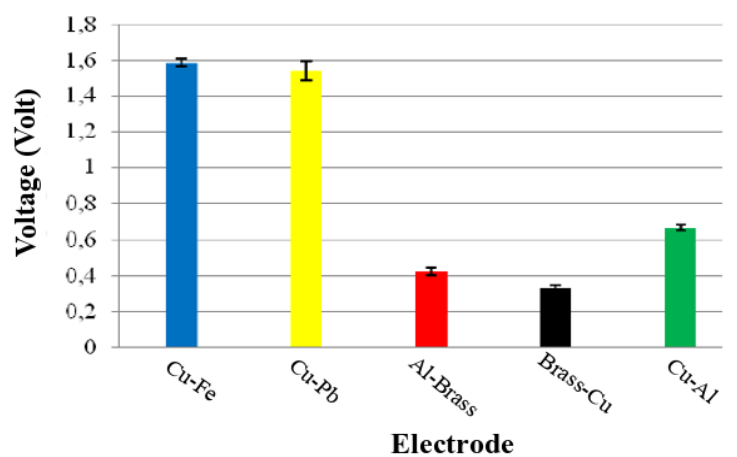

Figure 16. Graph of voltage measurement results on LED flames in series and parallel Bio-batteries (Imamah, 2013).

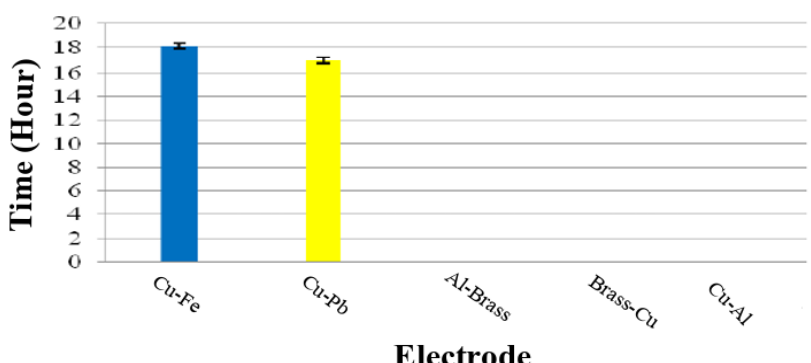

Figure 17. Graph of Results of Old LED Flash Measurements in Series and Parallel Bio-Batteries (Imamah, 2013).

\section{CONCLUSIONS}

There are various parameters that affect the electrical properties of fruits and vegetables. Different types of fruits and vegetables produce different currents and voltages depending on their characteristics. Some parameters that are known in this study are $\mathrm{pH}$ (acidity level), type of electrode used, distance between electrodes, how to install bio-batteries in series or parallel, and the voltage generated by bio-batteries.

Based on the research that has been done shows that $\mathrm{pH}$ is inversely proportional to current and voltage. In addition, the type of electrode used also affects the electrical properties. The distance between electrodes will be inversely proportional to the current and voltage in fruit and vegetable waste. While installing biobatteries in series and parallel can increase current and voltage. Bio-batteries with a higher voltage will produce longer LED flash times.

Through research that has been done, fruits and vegetables have the potential to be used as an alternative source of electrical energy.

\section{ACKNOWLEDGEMENTS}

The author would like to thank the Faculty of Science and Technology UIN Sunan Kalijaga and the journal "Biology, Medicine, \& Natural Product Chemistry" who have collaborated in holding the International Conference on Science and Engineering (ICSE) 2018.

\section{REFERENCES}

Amin, M. and Dey, P. "Electrochemical Analysis of Fruit and Vegetable Freshness", the WSEAS Transactions on Biology and Biomedicine, Issue 2, Volume 2, ISSN 1109-9518, pages: 214-219, April 2005.

Chang, Raymond. 2004. Basic Chemistry Third Edition Volume 2. Jakarta: Erlangga (In Indonesian).

Imamah. aisyah n. 2013. Effect of Electrode Material Variations and Variations Between Electrode Distance to Electrical Generated by Citrus Fruit Waste (Citrus Sp.). (Thesis). University of Jember. East Java. (In Indonesian)

Jauharah, Wira Dian. 2013. Analysis of Electricity Produced by Fruit Waste and Vegetables as Alternative Energy Bio-Batteries. (Thesis). University of Jember. East Java . (In Indonesian).

Kartawidjaja. M, Abdurrochman. A, Rumeksa. E. 2008. Proceedings of the National Science and Technology Seminar-II2008. Housing: University of Lampung: 105-115. (In Indonesian).

Kholida, Hana and Pujayanto. 2015. The Relationship of Strong Electric Current with the Acidity of Citrus and Mango Fruits. Proceedings of the 6th National Seminar on Physics and Physical Education (SNFPF). (In Indonesian).

Muhlisin, Muh et al. 2015. Utilization of Banana Skin Waste and Durian Skin as an Alternative Substitute for Stone Battery Paste. Journal of Electrical Engineering and Technology Volume 9, No. 3. (In Indonesian). 
THIS PA GE INTENTIONALLY LEIT BLANK 